\title{
Significance of Ophiolite Emplacement in the Development of Ninetyeast Ridge, South Andaman Island, Indian Ocean
}

\author{
SK Tiwari ${ }^{1}$, SK Barman ${ }^{2}$ \\ ${ }^{1}$ Associate Professor and Dy. Director, UGC- ASC (HRDC), Adjunct Faculty, Department of Geology, Centre of Advanced Study, Institute \\ of Science, Banaras Hindu University, Varanasi, Uttar Pradesh, India
}

${ }^{2}$ Ph.D Scholar, Department of Geology, Institute of Science, Centre of Advanced Study, Banaras Hindu University, Varanasi, Uttar Pradesh, India

\begin{abstract}
Burmese Arc evolved since late Mesozoic in consequence to eastward subduction of Indian lithosphere at the continental margin of Southeast Asia. Burmese Arc, together with Andaman Arc further south, acts as an important transitional link between the collisional phase of Himalaya on the north and Sunda Arc (a typical consumptive margin) to the south, the latter is in direct tectonic continuation with the western Pacific Arc System. With the advent of Plate Tectonics this arc has been the site of renewed geoscientific studies since the region provides an excellent scope to test various geologic models owing to its transitional tectonic set up between a truly collisional phase (of Himalaya) and a typical consumptive margin (Sunda Arc), where, surface geology, Aerial Photographs and interpretation of Satellite Imageries put important constraints for any tectonic model chosen. Andaman-Nicobar islands in the north eastern Indian Ocean, forms an arcuate chain, which lies at the intersection of Indian and Pacific lithospheric plates. Recent geological investigations reveal that an almost continuous marine sequence of late Mesozoic to Pleistocene age except the "Ophiolite Suite" occurs on these islands. Ophiolites are an assemblage of mafic and ultramafic lavas and hypabyssal rocks found in association with sedimentary rocks like Greywackes and Cherts. The Ophiolite complex constitutes the Peridotite and their Serpentinised equivalent and basic to intermediate volcanic rocks. These rocks reflect a phase of ultrabasic and basic intrusions which continued till the Eocene and may represent igneous activity connected most probably with Deccan Trap activity $(70.45$ mya). The significance and origin of ophiolites is a matter of interest to geologists. Many investigators interpret ophiolites as slices of oceanic crust which have been technically emplaced in orogenic belts. Serpentinization of Peridotite may explain the origin of Ninetyeast ridge and presence of Low Velocity Zone $(L V Z)$ in the upper most mantle beneath the ninetyeast ridge. In the present article, a review study is presented in relation particularly to serpentinisation below the Burmese Arc, stress pattern etc. The results are next interpreted to study emplacement of Serpentinites and related tectonics of the region.
\end{abstract}

Keywords: Andaman - Nicobar Islands, Ophiolites, Deccan Trap Activity, Peridotites, Serpentinisation, LVZ, Ninetyeast ridge

\section{Introduction}

Himalayan-Tibetan orogen developed as a result of the collision of India with Eurasia (Allegre et al., 1984; Dewey et al., 1989; Yin and Harrison, 2000; Searle et al., 2006; Guilmette et al., 2009). This collision started about 65 mya (Klootwijk et al., 1992), and the amalgamation of the involved continental blocks (Klootwijk et al., 1992; Matte et al., 1997; Yin and Harrison, 2000) occurred along YarlungZangbo Suture Zone in late Cretaceous to early Tertiary (Windley, 1988; Hébert et al., 2012). Some of the ophiolites along this suture zone (Loubusa ophiolite) contain in-situ diamonds and ultra high pressure minerals in their upper mantle peridotites and chromitites (Yang et al, 2007).

Ophiolites are fragments of oceanic plate (oceanic crust and the underlying upper mantle) that have been thrusted/emplaced/uplifted/obducted onto the edge of continental plates to be exposed within continental crust. The term was originally used by [8] for an assemblage of green rocks (Serpentine, Diabase) in Alps. Ophio is Greek for snake while lite means stone/ rock. [40]; later modified its use to include Serpentine, Pillow lava and Chert. These are assemblages of ultramafic and mafic lavas and hypabyssal rock found in association with sedimentary rocks Greywackes and Cherts [25] and occur as mélange (tectonic mixture of fragments). [13], also defined
Ophiolites as "suites of temporally and spatially associated ultramafic to felsic rocks related to separate melting episodes and processes of magmatic differentiation in particular oceanic tectonic environments. Their geochemical characteristics, internal structure, and thickness are strongly controlled by spreading rate, proximity to plumes or trenches, mantle temperature, mantle fertility, and the availability of fluids".

These were first discovered from Alps in early 20th century and were later discovered from almost every orogenic belts. These are considered as geologic window into the history of Earth [15], [24]. Ophiolites have always played a central role in Plate Tectonic Theory. Ophiolite assemblages records structural, magmatic and metamorphic processes that preceded their entrapment in orogenic belts by continental and plate collisions [13].

Arakan-Burma ranges in the west are bordered by Himalaya, Andaman-Nicobar ridge system which forms southward continuation of Arakan-Yoma, Burma Arc forming the boundary between Indian and Eurasian Plate in the east. Andaman-Nicobar group of islands form an arcuate chain extending for about $850 \mathrm{~km}$. bounded by lat. $6^{\circ} 45^{\prime} \mathrm{N}$ and $13^{\circ} 45^{\prime} \mathrm{N}$ and by long. $90^{\circ} 15^{\prime} \mathrm{E}$ and $94^{\circ} 00^{\prime} \mathrm{E}$. The Islands Arc can be separated in to two concentric arcs- outer (western) sedimentary comprising major islands of 


\section{International Journal of Science and Research (IJSR) \\ ISSN (Online): 2319-7064}

Index Copernicus Value (2015): 78.96 | Impact Factor (2015): 6.391

Andaman-Nicobar and inner (eastern) volcanic comprising Narcondam and Barren islands which occur as conical volcanoes above sea level. A third arc to west of AndamanNicobar is in the process of emergence [16]; Reported formation ages of Ophiolites show three distinct peaks called Ophiolite pulses. Ophiolite released during each pulse corresponds to the period of worldwide magmatic event as represented by voluminous granite intrusion and tend to form a particular Ophiolite belt. Late Proterozoic (ca. $750 \mathrm{Ma}$ ) Ophiolites are distributed in Pan-African orogenic belt, early Palaeozoic (ca. $450 \mathrm{Ma}$ ) Ophiolites appear in Appalachian-Caledonian-Uralian belt, and Mesozoic (ca. $150 \mathrm{Ma}$ ) Ophiolites dominate AlpineHimalayan belt [32].

\section{International status}

Ophiolite sequences of various provinces of Ophiolites of the world viz. Orogenic belt, Caledonian have been dealt by several author's such as Norway (Furnes et al. 2012), Scotland (Sawaki et al. 2010), Ireland (Hollis et al. 2012, 2013) ; Appalachian, Canada (Page et al. 2009); Uralian, Kazakhstan (Savelieva et al. 1997; Savelieva 2011); Central Asian, Mongolia (Buchan et al. 2001, 2002; Jian et al. 2010), China (Zheng et al. 2013);

Qingling-Qilian- Kunlun, China (Xia and Song 2010), Bangong-Nujiang Suture, China (Jian et al. 2009), Tibet (Zhai et al. 2013); Hercynian, Poland (Floyd et al. 2002), Spain (Pedro et al. 2010); Alpine-Himalayan, SE Spain (Puga et al. 2011), Italy (Charlot-Prat 2005; Manatschal et al. 2011), Corsica (Saccani et al. 2008), Albania (Dilek and Polat 2008), Greece (Pe-Piper et al. 2004; Dilek and Furnes 2009), Cyprus (Rautenschlein et al. 1985), Turkey (Dilek and Thy 2009), Iran (Saccani et al. 2010), Pakistan (Khan et al. 2007), India (Mahéo et al. 2004), Tibet (Bezard et al. 2011); Andean, Colombia (Kerr et al. 1997), Argentina (Gonzáles- Menéndez et al. 2013), Indonesian- Myanmar India (Singh et al. 2012), Andaman island (Pedersen et al. 2010), Central Indonesia (Monnier et al. 2003)

The reconstruction of the tectonic evolution of the Indonesian region (Mesozoic- Cenozoic IndonesianMyanmar orogenic belt) has been dealt in detail by Hall (2012) which reveals a complex magmatic and tectonic history that evolved during the closure of the Meso-Tethyan Ocean. The Paleozoic orogenic belts are represented by collisional and accretionary types (Isozaki, 1997; Condie, 2007; Windley et al., 2007; Cawood et al., 2009; Wilhemet al., 2011). The example of the collisional orogenic type is Himalayan belt.

\section{Present Study}

In the present study remote sensing data (SPOT image) has been used in preparation of the detailed geological map of the southern Andaman area (Fig.1) bounded by Lat. $11^{0} 44^{\prime} 07.01^{\prime \prime} \mathrm{N}$ and Long. $92^{0} 31^{\prime} 06.84^{\prime \prime E}$, Lat. $11^{0} 44^{\prime} 57.02^{\prime \prime} \mathrm{N}$ and Long. $92^{0} 45^{\prime} 23.39^{\prime \prime} \mathrm{E}$, Lat. $11^{0} 27^{\prime} 00.62^{\prime \prime} \mathrm{N}$ and Long. $92^{0} 47^{\prime} 43.23^{\prime \prime E}$, Lat. $11^{0} 26^{\prime} 13.19^{\prime \prime} \mathrm{N}$ and Long. $92^{0} 3327.57^{\prime \prime} \mathrm{E}$ with the help of GIS techniques. [27], [41], [19]; surveyed different parts of these islands and attempted to prepare a geological map for the first time. Base line data has been adopted from [41], Boileau (1950), Jafri (1986) and [38]. The satellite data has also been studied and analysed to demarcate the existence and extent of Ninetyeast ridge.

The Ophiolites present in the area were studied in detail in the field as well as in the laboratory under advance petrological microscope to observe the mineralogical characteristics and assemblages so as to understand its association with Port Blair Group (Table-1) predominant in the area in particular and other Groups in general as well as its genesis and mode of emplacement.

\section{Geological Setting}

Indo-Burman ranges mark the northward continuation of the Andaman-Nicobar arc where the Indian Ocean floor is subducted beneath the southeastern Asian Continent. Andaman Ophiolite belt marks the southern extention of Manipur and Burmese Arakan-Yoma Belt, which is the easternmost continuation of Tethyan Belt and belong to a region of distinct structural and topographical belt that trends north-south and then turns eastward from Sumatra towards Java. Ophiolites of Makran and Central Iran form discontinuous linear belts of Tethyan oceanic fragments, which form a bridge between Mediterranean and Himalayan Ophiolites (Ghazi, 2003). Similar to Arakan-Yoma, Ophiolites of Andaman Islands have intruded in the folded arenaceous, argillaceous and calcareous sediments of Cretaceous age. A thick sequence of Tertiary rocks overlie Andaman Ophiolite complex under fluctuating shallow to deep water conditions [10].

In Andaman islands the Cretaceous Ophiolites (Serpentine Group of [41] and Ophiolite Suite of [23] and overlying Palaeocene to lower Miocene sediments are folded, reverse faulted and overlain by that lying uppermost Miocene to Recent (reef derived) deposits (Chatterjee, 1964); [23] like the Palaeocene rocks of Arakan-Yoma and Mentawai island [42], suggesting the broad structural history of ArakanYoma of Burma (Myanmar), Andaman-Nicobar islands is almost similar.

Classification of ophiolites through time: The ophiolite occurrences are principally of two age groups - an older group around 170-140 Ma and a younger group around 125$90 \mathrm{Ma}$. There are many difficulties in providing a waterproof classification of the ophiolites, particularly the oldest, and there are many conflicting views regarding many of the Pre-cambrian greenstone sequences and also some of the Phanerozoic complexes. Several authors have used the geochemical data for greenstone sequences that have been considered to represent some sort of oceanic crust, and then applied the geochemical approach to classify them according to the recently introduced ophiolite classification [13], Based on their geochemical data, field, regional tectonics and lithological characters researchers have divided the Phanerozoic and Precambrian ophiolite complexes into subduction-related and subduction unrelated sequences. It has been observed that $75 \%$ and $85 \%$ of the Phanerozoic and Precambrian greenstone sequences, respectively, are subduction-related. 


\section{International Journal of Science and Research (IJSR) \\ ISSN (Online): 2319-7064}

Index Copernicus Value (2015): 78.96 | Impact Factor (2015): 6.391

Subduction related ophiolites: These represent destructive stages of ocean floor recycling (subduction with or without seafloor spreading), and their magmatic products are characterised by showing variable geochemical fingerprints, indicating subduction influence. These are further divided into:

SSZ-backarc: Represented by a predominance of MORBtype greenstones which is by far the dominant Phanerozoic ophiolites $(56 \%)$, as are also for the Precambrian greenstones $(45 \%)$.

- SSZ-backarc to forearc: Represented by the sequences that show approximately equal proportions of MORB, IAT and Boninites, are the second most abundant group of Phanerozoic ophiolites (27\%), and are also well represented $(22 \%)$ with the Precambrian greenstone sequences.

- SSZ-forearc: Characterized by the sequences consisting of boninites which is of minor abundance among the Phanereozoic and Precambrian greenstones?

- SSZ to Volcanic Arc: Have a dominant continental arc signature and is rarely represented among the Phanerozoic ophiolites, but shows a significant proportion (26\%) among the Precambrian ophiolites.

\section{Ophiolites in South Andaman}

The Ophiolites consist of Serpentinite, Ultrabasics, Basic rocks (plutonic and intermediate volcanic) and Cherts. Except Serpentine Group all other rocks encountered on these islands are marine deposits (Late Cretaceous to Recent). The volcanics occupy a major portion of South Andaman Islands. To the south of Port Blair all along the east coast they are traceable over a distance of $17 \mathrm{~km}$. from Carbyn's Cove right up to the Chidia Tapu in South Andaman. On the basis of detailed petrographic study of various rock types; based on the concept followed by [20], [28]; authors have identified following volcanic units (Table-2) in the Ophiolites:

Peridotite Suite: Most widespread members of the ultrabasic class are highly magnesian rocks consisting predominantly of Olivine or its hydration productsserpentine minerals. These are Peridotites and Serpentinites (composed largely of Serpentine minerals) - the latter, strictly speaking- metamorphic rocks [33]. By virtue of texture and mode of emplacement Peridotites conventionally here can be classed as Plutonic Igneous rocks. Large bodies of Peridotites are found in mobile geosynclinal belts (commonly largely converted to Serpentinite). Here, mantle Peridotites appear to have been pushed up through a thin crust to above sea level. Peridotites in all stages of serpentinisation are now believed to represent fragments of sub-oceanic crust and mantle rock that have been tectonically emplaced in the solid state at their present sites in mobile belts. Texture and field transitions to Peridotite show beyond doubt that most serpentinised bodies were formed by hydrothermal metasomatism of Peridotites of the Ophiolitic type. Peridotites and their Serpentinised equivalents are exposed in Carbyn's Cove, Chidia Tapu and Birchganj area, South Andaman. These rocks are pervasively altered to Serpentinite. Pyroxenes-especially Enstatite and Calcic Plagioclase are next in abundance to Olivine in these rocks.
Within Dunite (dominated by Olivine), Chromite has been encountered.

Mafic Suite: These rocks are well exposed about 1.5-2 km. south-east of Chidia Tapu area, South Andaman. These rocks include Basalts (volcanic), their plutonic counterpart Gabbro (Plagioclase being the most abundant single mineral) and Dolerite (a hypabyssal rock, moderately dark, heavy, and minutely crystalline).

Acidic Suite: This suite is also developed in Chidia Tapu area. Unfortunately rocks of these suites could not be well studied due to highly fissile and fractured nature imparting a brecciate appearance at places and hence have not been considered in the present study.

On the basis of the microscopic features and field occurrence, various other types of rock components associated with Ophiolites have also been identified. Besides volcanics, Ophiolites are associated mainly with Cherts, Shales and Greywackes of Port Blair Group. Cherts are tough, nonporous sedimentary rocks of somewhat vitreous luster composed largely of authigenic silica. Here, Cherts are with tests of Radiolarians and can be referred as Radiolarian Cherts. However, these organic remains are scattered and have lost their detail, and many are no more than round or oval forms. Here, bedded Radiolarian Cherts occur as in eugeosynclinal assemblages elsewhere and are associated with Serpentinites, Basalts and bedded Cherts that collectively make up the compound lithologic assemblage known as Ophiolite. Now, Ophiolites are generally interpreted as segments of oceanic crust. Radiolarites typically accumulate on the deep ocean floor, and their origin may perhaps be connected with concurrent volcanic activity on the sea floor.

Greywackes, a widespread type of Sandstone, occur in this orogenic belt of early Tertiary or pre- Tertiary age. Majority of them are graded sandstone beds in Flysch sequencesAndaman Flysch [23]; and were presumably deposited by turbidity currents in deep marine basins.

\section{Structure and Tectonics}

The Ophiolites of the study area are highly sheared, fractured, mylonitised and have developed schistosity [33]; near shear zones developing highly friable and crushed rocks resulting in to tectonic autoclastic conglomerate. More intense strain is manifested by progressively more conspicuous foliation, streaked texture and reduction in grain size of Olivine (so called granulation) by recrystallisation at relatively high strain. The ultimate result is Mylonitic texture. At times, the schistosity is folded. The Ohiolites are characterized by conjugate set of fractures filled with secondary recrystallized quartz and/or calcite. On different sections the angular relationship varies depending on the orientation of fracture and outcrop faces on which it is observed. The orientation of fracture suggests that amount and direction of plunge of the principal stresses responsible for the development of the fractures $\mathrm{S}_{1}, \mathrm{~S}_{2}, \mathrm{~S}_{3}$ is $25^{0}-55^{0} \mathrm{~W}$, $37^{0}-40^{0} \mathrm{~N}, 62^{0} \mathrm{E}$ respectively [18]. The stress orientation in the area is highly heterogeneous and is difficult to be strictly 


\section{International Journal of Science and Research (IJSR) ISSN (Online): 2319-7064}

Index Copernicus Value (2015): 78.96 | Impact Factor (2015): 6.391

associated with any structure due to the east- west convergence of the Indo-Burman Ranges [4].

Blocks of Ophiolite complex are affected by steeply dipping faults and shear surfaces trending in northwest - southwest and north south directions. The Ophiolites along with sediments of Cenomanian age are strongly deformed giving rise to low to moderately or high plunging synclines and anticlines with rarely overturned and have their axes trending in northwest - southeast or north south direction.

South of Port Blair, Ophiolites (late Cretaceous) are exposed along the east coast, from south of Carbyn's cove to Birchaganj and then to Chidia Tapu area. These show faulted contact with younger Port Blair Group rocks ( late Eocene to Oligocene), as revealed by the presence of faulted breccias containing pebbles of basic rocks, Cherts and Quartzites in a sandy matrix showing unconformable relationship between Ophiolites and younger rocks.

Near Carbyn's cove the fault limiting the northern extent of Ophiolites strikes in east-north, east-west and south-west direction and steeply dips in north direction thus northern sides forming the down throw blocks brings younger Port Blair Group rocks in contact with the older Ophiolites exposed on the southern sides which form the up throw side block. On the western side of Carbyn's cove the NNW-SSE striking fault displaces the ENE-WSW striking fault which is steeply dipping forms the western side the down throw block and the eastern side forming the up throw side block resulting in to the contact of older Ophiolite on the east and younger Port Blair Group on the west. There is also a small outcrop of conglomerate near Carbyn's cove containing pebbles of basic rocks, cherts and quartzite's and proves the non-confirmity between the Ophiolite and Port Bair Group.

\section{Tectonic Significance of Serpentinites}

Ophiolites as analogus of ocean crust are studied extensively to decipher extensional processes at oceanic spreading centers and their distribution and geochemical signatures are essential in modeling of tectonic evolution of ocean basins. However, less well studied is the deformation encountered during a relatively rare event among earth processes - ophiolite emplacement itself. Emplacement processes span the period during which an ophiolitic slab is transposed from its extensional setting of igneous origin to its final position in a continental margin within a convergent plate boundary. This lithospheric-scale process entails extensive lateral and vertical offset. Ophiolites are expected to record the structural, textural, and mineralogical evidence for the essential mechanisms of these displacements, allowing us to constrain the kinematics within an oceanic slab in tectonic transport [30].

The Serpentinite bodies (hydrothermally altered Peridotites) in Andamans antidate the flysch facies sequence and have contributed material to the later. These are rocks of great petrologic- tectonic interest. The problem of Serpentinite bodies, their formation and emplacement in relation to geotectonics has been discussed here.
There are two schools of thoughts regarding their mode of emplacement. One school of thought led by Bowen believes in solid intrusion of Serpentinites, while others [21], [2]; support the hypothesis of Peridotite magma. Their internal structures, appearance and their body parallelism with prevalent shear directions suggests that shear of surfaces reaching down to the Peridotite layer below the Moho might have facilitated the emplacement of these bodies. Ophiolites of Late Cretaceous in Pakistan Himalaya were emplaced in a belt trending parallel to regional structures and lineaments [1]. Nevertheless, the intrusive relationship of Serpentinites as evidenced by their discordant contact and their contact metamorphic effects [43], [9], [10], [3]; and occurrence of some concordant sills of Peridotite and Serpentinites [22]; are evidences against the views of those led by Bowen who favour solid intrusion [21]. Later, [22]; revised and suggested that the Alpine type Serpentinite might have originated in the Peridotite layer before emplacement and their subsequent mobility is due to interestial water vapour and relative amenability of olivine to flow under stress [6]. In their opinion Serpentinization of the Peridotites (Dunites in this case) below the Moho, is accompanied by a volume increase upto a maximum of $25 \%$, limited by increase in Enstatite content as per the following equation :

Olivine + Water $=$ Serpentine $($ Antigorite $)+$ Brucite + Heat, $2 \mathrm{Mg}_{2} \mathrm{SiO}_{4}+3 \mathrm{H}_{2} \mathrm{O}=\mathrm{Mg}_{3} \mathrm{SiO}_{2} \mathrm{O}_{5}(\mathrm{OH})_{4}+\mathrm{Mg}(\mathrm{OH})_{2}$

Enstatite, when present, certainly plays a part in the Serpentinisation process. In the presence of water, the pair Olivine-Enstatite becomes unstable and could be replaced by Antigorite and Talc at temperatures as high as about $500^{\circ} \mathrm{C}$ and above.

Experiments show that at pressures corresponding to a depth of a few kilometers, magnesian olivine in continuous contact with a flux of pure $\mathrm{H}_{2} \mathrm{O}$ is unstable at temperatures below about $500^{\circ} \mathrm{C}$. The stable product of hydration in a system closed except to aquous fluid is Serpentine and Brucite. The reaction proceeds to the right at $500^{\circ} \mathrm{C}$ or less depending upon the super incumbent pressure. The volume increase will initially caused the epiorogenic uplift of the basinal area lying directly above the swell of the Peridotite substratum and a part of the serpentine mass may as well pass up the resultant fractures. Hence, the vertical movement will include subsidence and uplift due to processes of serpentinization and deserpentinization. In the Andamans (south and middle) development of the parallic facies represented by black shale might have been a result of this uplift of the sea ocean basin linked to the serpentinization of the Peridotite layer. [26]; have postulated that emplacement of the Serpentinite in a rather hot state took place in the transition stage when the tectonics of the area passed from one primarily of horizontal pressure to another combining vertical adjustment with it the later reflected in the initiation of wild flysch and flysch.

If we accept the proposition that ophiolites, if well preserved and not altered by events unrelated to lithosphere accretion, are representative of oceanic crust, one has to first test this proposition by observing whether representative ophiolite samples had measured velocities compatible with the seismic layering defined for oceanic crust. If the velocities of ophiolite samples were compatible with the 


\section{International Journal of Science and Research (IJSR) \\ ISSN (Online): 2319-7064}

Index Copernicus Value (2015): 78.96 | Impact Factor (2015): 6.391

range of seismic velocities recorded for oceanic crust, then one can hope to use the ophiolite measurements to understand better the details of the seismic layering of oceanic crust (Peterson, 1974).

The wave velocity studies [35], [36]; supports that the serpentinization of Peridotite (chemical differentiation in upper mantle) may explain the origin of Ninetyeast ridge and does not supports the hypothesis that Ninetyeast ridge was formed on hot, relatively weak lithosphere which is essential with formation at or near an oceanic spreading center by a mantle plum or hot spot. [36] suggested a thick crust of $23 \mathrm{~km}$. thickness across Ninetyeast ridge and that this anomolous crustal thickening may be explained by assuming the gradual transformation of top mantle material in to material having either crustal velocity or slightly lower than Moho velocity (p-wave velocity $7.72 \mathrm{~km} /$ second, swave velocity $4.45 \mathrm{~km} / \mathrm{second}$ ). The wave velocity studies by him across the north and Central Indian ocean suggests the presence of a low velocity zone of $90 \mathrm{~km}$. thickness (with p-wave velocity of $7.85 \mathrm{~km} /$ second and s-wave velocity of $4.37 \mathrm{~km} / \mathrm{second}$ ) which may be caused by the partial melting and high temperature of $1100^{\circ} \mathrm{C}$ to $1200^{\circ} \mathrm{C}$. Wave velocity studies by [37], [35], [36]; reveals that except for a thick anomalous crust the structure beneath the aseismic ridge of eastern Indian ocean i.e. Ninetyeast ridge is quasi oceanic and that the upper most $30 \mathrm{~km}$. of the mantle have lower velocities. Souriau, 1981 rules out a thermal origin while a model with serpentinised Peridotites as proposed by [7] which fits gravimetric data is able to explain the low velocities of uppermost mantle beneath Ninetyeast ridge.

\section{Conclusion}

The present findings on the mode of emplacement of Serpentinites, based on the field evidences, lithological associations and petrographic studies of the serpentinized bodies of the Andaman are well supported and justified by the studies of [7]; wave velocity studies of [37], [35], [36]; favouring solid intrusion of the Serpentinites along Ninetyeast ridge in Indian Ocean. With the availability of sophisticated instruments, the Ophiolite- petrogenesis may now be deciphered in the light of geochemistry. Of course, sound field relations of the Ophiolite suite with detailed knowledge of structural setting would be utmost needed as background information. Although in Indian sub-continent, researches on Phanerozoic Ophiolite occurrences on parts of northwestern and northeastern Himalayas as well as on Andaman region started since long, owing to scattered nature of the research data, it is imperative now to systematize those in a classified manner.

Every few years the people working on Ophiolites and those who work on oceanic crust decide that it is time to get together and compare notes. The Ophiolite people are primarily traditional "land" geologists who combine geologic mapping with structural, petrologic, and geochemical studies. The ocean crust people are primarily marine geologists and geophysicists who drill and dive on the real thing. There is some overlap of people who do both, but since most do either one or the other, these get-togethers are a critical reality check for everyone.

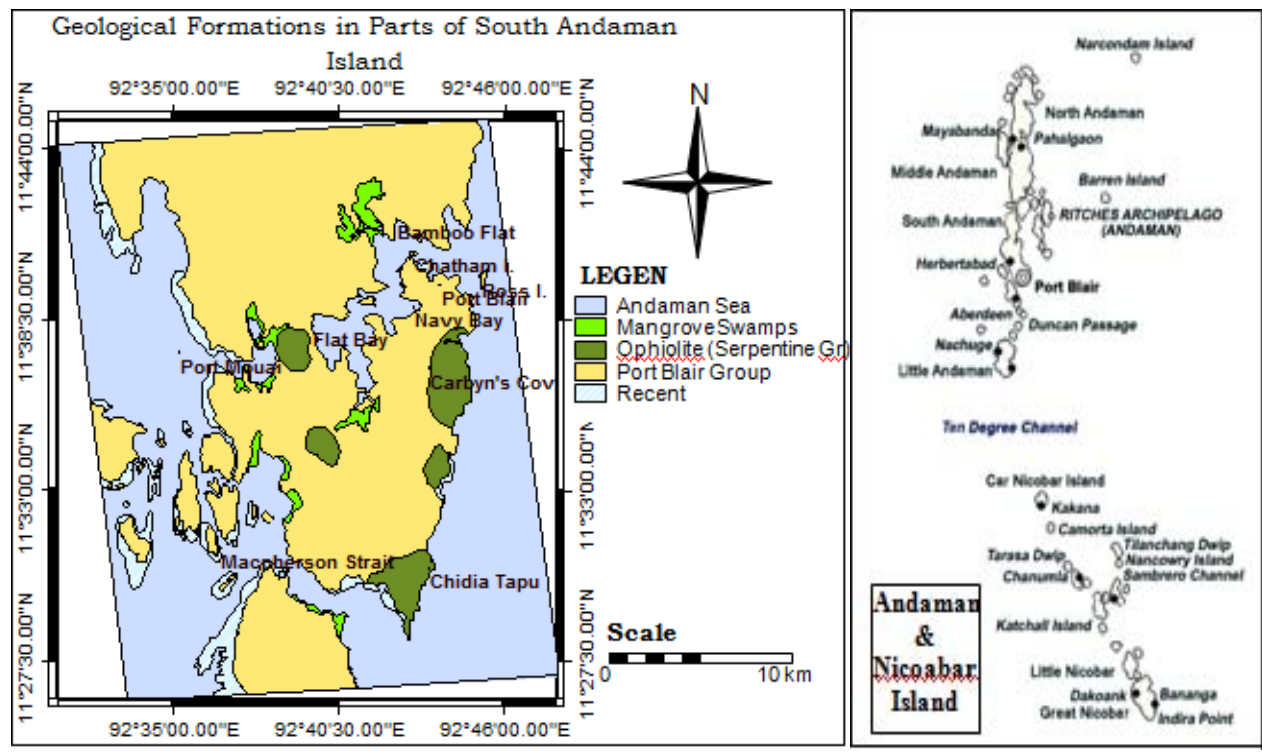

Figure 1 (b): Location \& Geological Map of South Andaman Island 
Annexure - 1 (Details of Photographs)

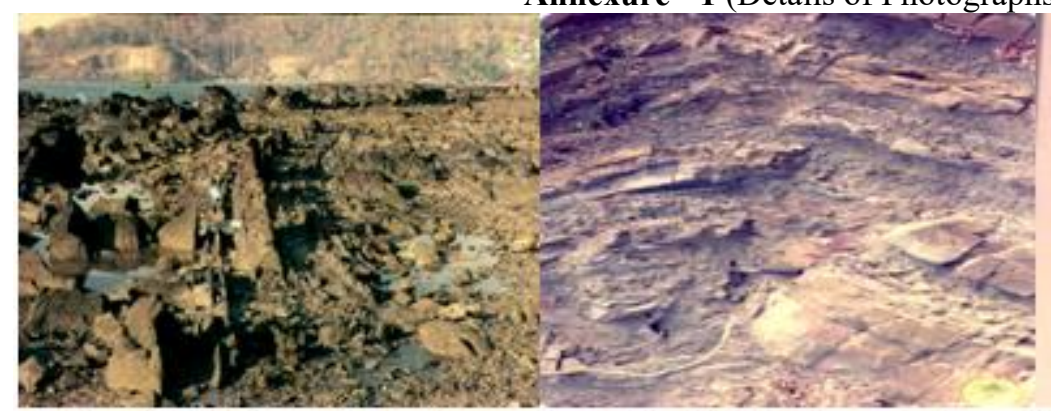

Photo 1. Field Photograph of arcuste shaped Graywacke-Shale sequence of Portblair Group near Carbyn's Cove.
Photo 2. Field photograph of folded Grayacke-Shale sequence with volcanoclastic Breccia,, Hope Town quarry.

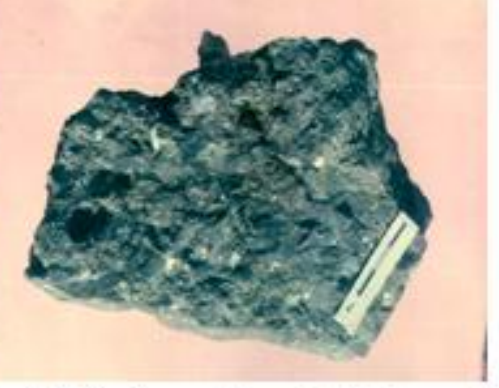

Photo 3. Specimen photograph of volcanoclastic Breccia with fragments of ultrabasic and basic rocks and Cherts.

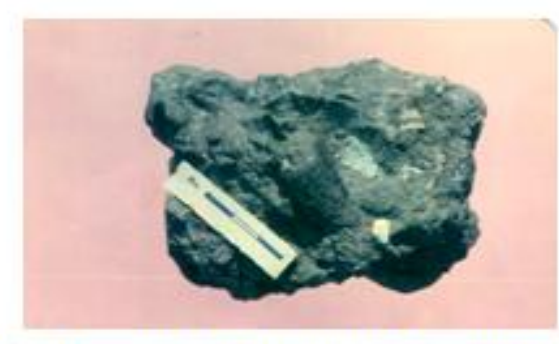

Photo 4. Hand specimen photograph of volcanoclastic

Breccia with angular pebbles of ultrabas ic and basic rocks,

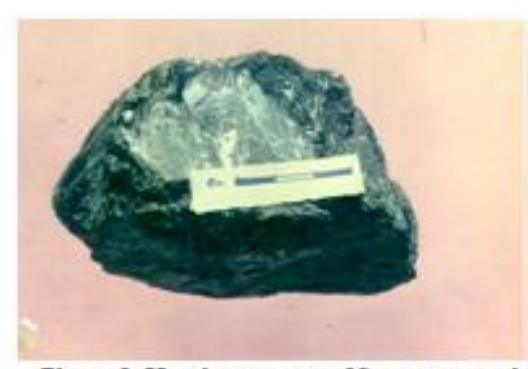

Photo 5. Hand specimen of Serpentinised Ophiolites traversed by Calcite veins.

Annexture - 2 (Details of Microphotographs)

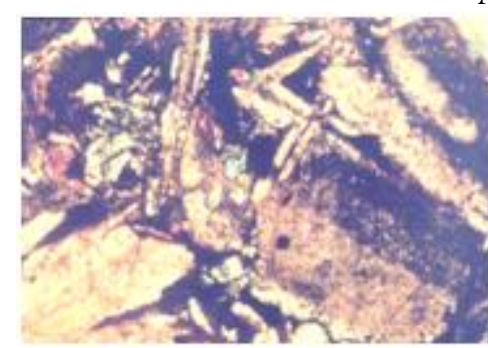

Photo 1 altered fine grained Dolerite grading in to coarse grained Gabbro.

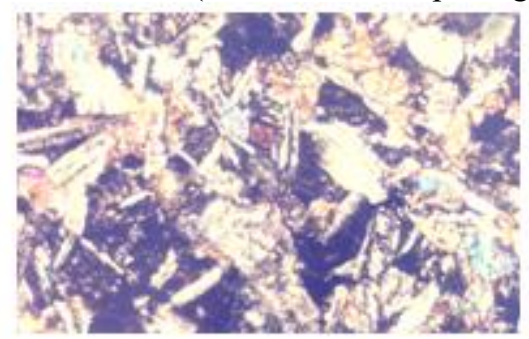

Photo 2. Dolerite with Ophitic texture showing Labrodorite laths in Augite crystals.

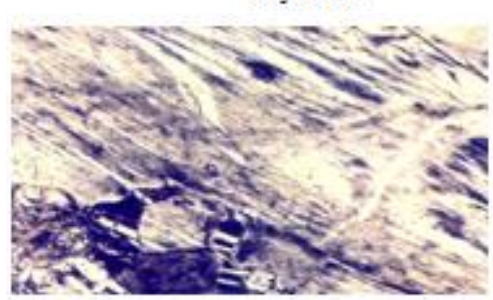

Photo 4. Serpentinite showing characteristic lamellar form and pesudomorph of Olivine and veins of Phlogopite in Calcite.

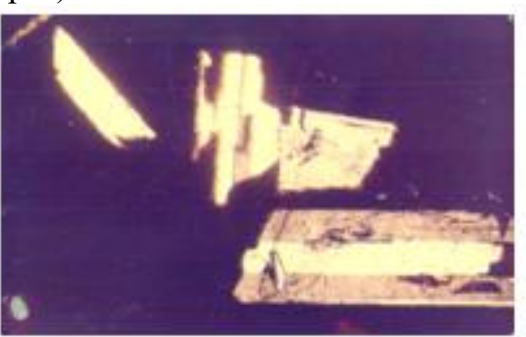

Photo 3. Vitrophyric Basalt showing Labrodorite laths embedded in glassy ground mass.

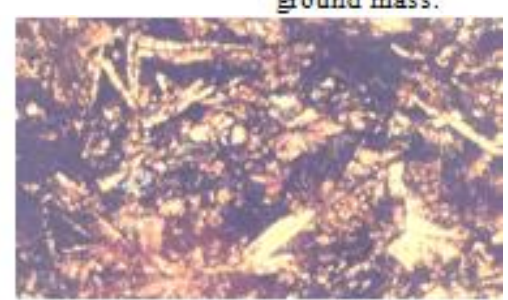

Photo 5. Basalt showing Porphyritic texture. Labrodorite embedded in fine grained crystalline ground mass of Augite, Labrodorite and Glass.

Table 1: Geological Succession of Andaman- Nicobar Group of Islands (After Srinivasan, 1986), [5]

\begin{tabular}{|c|c|c|}
\hline Group & Formation & Epoch/Age \\
\hline & $\begin{array}{c}\text { Shaly Limestone, Coral rags and Beach Sands } \\
\text {-------Unconformity-------- }\end{array}$ & Recent to Sub-recent \\
\hline $\begin{array}{c}\text { Archipelago } \\
\text { Group } \\
(>1500 \mathrm{~m})\end{array}$ & Neil West Coast Formation & $\begin{array}{c}\text { Pleistocene (Younger than 1.95 m.y.) } \\
\text { Late Pliocene (3-1.95 m.y.) } \\
\end{array}$ \\
& Guitar Formation & Late Miocene -Late Pliocene (10-3 m.y.) \\
& Sawai Bay Formation & Late Miocene-Early Pliocene (10-3 m.y.) \\
& Long Formation & Middle - Late Miocene (13 - 5 m.y.) \\
& Inglis Formation & Early - Middle Miocene (17.2-13 m.y.) \\
& Round Formation & Early Miocene (22.5-17.5 m.y.) \\
& Strait Formation & \\
\hline
\end{tabular}

Volume 6 Issue 1, January 2017 www.ijsr.net 


\section{International Journal of Science and Research (IJSR) \\ ISSN (Online): 2319-7064}

Index Copernicus Value (2015): 78.96 | Impact Factor (2015): 6.391

\begin{tabular}{|c|c|c|}
\hline $\begin{array}{c}\text { Portblair } \\
\text { Group } \\
(>5000 \mathrm{~m})\end{array}$ & $\begin{array}{c}\text { Alternately bedded grey Sandstone, Shales } \\
\text { (Andaman Flysch), Conglomerates and Grits } \\
------- \text { Unconformity--------- }\end{array}$ & Late Eocene-Oligocene (?) (45-25 m.y.) \\
\hline $\begin{array}{c}\text { Baratang } \\
\text { Group } \\
(>2000 \mathrm{~m})\end{array}$ & $\begin{array}{c}\text { Grey Shales, Siltstones, Grey impure } \\
\text { Limestones etc. }\end{array}$ & Late Cretaceous -Paleocene (70-50 m.y.) \\
\hline $\begin{array}{c}\text { Serpentine } \\
\text { Group }\end{array}$ & $\begin{array}{c}\text { Serpentinites, Ultrabasic and Basic plutonics, } \\
\text { Basic and Intermediate volcanics and } \\
\text { agglomerates. } \\
\text {-------Igneous Contact }\end{array}$ & Late Cretaceous - Eocene (70-45 m.y.) \\
\hline Porlob Group & $\begin{array}{c}\text { Older sedimentaries- Quartzites, Jaspers } \\
\text { Cherts, crystalline Limestones and Phyllites. } \\
\text { Base not exposed }\end{array}$ & Late Cretaceous (100 m.y.) \\
\hline
\end{tabular}

Absolute time relationship determined by caliberating microfossil datum levels with paleomagnetic and radiometric dates.

Table 2: Microscopic Character of Serpentinites Showing Various Assemblages

\begin{tabular}{|c|c|c|c|c|c|c|}
\hline $\begin{array}{l}\text { Sl. } \\
\text { No. }\end{array}$ & Rock Type & Nature & Essential Minerals & Accessary Minerals & Texture & Special Features \\
\hline 1 & Basalt & Volcanic & $\begin{array}{c}\text { Plagioclase (Labrodorite) } \\
\text { phenocrysts, Albite twinning } \\
\text { in fine grained crystalline } \\
\text { groundmass of Augite, } \\
\text { Labrodorite and glass }\end{array}$ & $\begin{array}{l}\text { Secondary Chlorite formed } \\
\text { by alteration of Pyroxene } \\
\text { found as cavities, vesicles, } \\
\text { round patches, Calcite as } \\
\text { cavities, Magnetite }\end{array}$ & Porphyritic & $\begin{array}{l}\text { Pyroxene shows } \\
\text { undulose extinction }\end{array}$ \\
\hline 2 & $\begin{array}{c}\text { Vitrophyric } \\
\text { Basalt }\end{array}$ & Volcanic & $\begin{array}{l}\text { Labrodorite and Augite in } \\
\text { glassy groundmass }\end{array}$ & $\begin{array}{l}\text { Microlites, Chlorite, } \\
\text { Calcite veins, Secondary } \\
\text { Phlogopite veins, Augite } \\
\text { altered to Limonite }\end{array}$ & Vitrophyric & $\begin{array}{l}\text { Augite altered } \\
\text { Limonite }\end{array}$ \\
\hline 3 & $\begin{array}{c}\text { Altered } \\
\text { Olivine } \\
\text { Basalt }\end{array}$ & $\begin{array}{l}\text { Volcanic } \\
\text { and } \\
\text { Plutonic }\end{array}$ & Feldspar laths with Augite & $\begin{array}{c}\text { Olivine, Chlorite, Opaque } \\
\text { minerals, Hematite, } \\
\text { Magnetite, Limonite }\end{array}$ & Ophitic & $\begin{array}{c}\text { Dolerite- fine grained } \\
\text { to Gabbro-coarse } \\
\text { grained, alteration in } \\
\text { Labrodorite } \\
\end{array}$ \\
\hline 4 & $\begin{array}{c}\text { Altered } \\
\text { Olivine } \\
\text { Basalt }\end{array}$ & Volcanic & $\begin{array}{c}\text { Augite and Olivine as } \\
\text { phenocryst with some Quartz } \\
\text { and Plagioclase in glassy } \\
\text { groundmass }\end{array}$ & Quartz & Porphyritic & $\begin{array}{l}\text { Olivine altered to } \\
\text { Serpentine very } \\
\text { commonly }\end{array}$ \\
\hline 5 & Dolerite & Volcanic & $\begin{array}{l}\text { Plagioclase laths in Augite, } \\
\text { Labrodorite shows lamellar } \\
\text { twinning }\end{array}$ & $\begin{array}{l}\text { Chlorite shows alteration } \\
\text { effect, Magnetite, Quartz }\end{array}$ & Ophitic & $\begin{array}{l}\text { Some Quartz and } \\
\text { Labrodorite deformed } \\
\text { and traversed by } \\
\text { cracks and fractures }\end{array}$ \\
\hline 6 & Andesite & Volcanic & $\begin{array}{l}\text { Plagioclase and Orthoclase as } \\
\text { phenocryst in glassy } \\
\text { groundmass or in groundmass } \\
\text { comprising microlites to } \\
\text { Feldspar }\end{array}$ & Calcite as veins, Magnetite & $\begin{array}{c}\text { Porphyritic to } \\
\text { Vitrophyric texture, } \\
\text { also pilotaxitic texture } \\
\text { is observed with } \\
\text { phenocrysts of } \\
\text { Oligoclase and } \\
\text { Hornblende scattered } \\
\text { in groundmass of } \\
\text { microlites of Feldspers }\end{array}$ & \\
\hline 7 & $\begin{array}{l}\text { Serpentinite } \\
\text { (altered } \\
\text { rocks) }\end{array}$ & \begin{tabular}{|c|} 
Altered \\
products of \\
original \\
peridotite \\
or \\
sometime \\
Dunite \\
rock
\end{tabular} & Olivine, Serpentine & $\begin{array}{l}\text { Calcite, Phlogopite Pyrite, } \\
\text { Chalcopyrite, Pyrrohtite, } \\
\text { Limonite, Hematite, } \\
\text { Magnetite, Chromite }\end{array}$ & & $\begin{array}{c}\text { Olivine altered to } \\
\text { Serpentine giving a } \\
\text { pseudomorph of } \\
\text { Olivine and shows } 2^{\text {nd }} \\
\text { colour. In some cases } \\
\text { Serpentine shows its } \\
\text { characteristic lamellar } \\
\text { form. Some Olivine } \\
\text { has been replaced by } \\
\text { Calcite veins of } \\
\text { Phlogopite seen in } \\
\text { Calcite crystal or } \\
\text { veins. }\end{array}$ \\
\hline
\end{tabular}




\section{International Journal of Science and Research (IJSR) \\ ISSN (Online): 2319-7064}

Index Copernicus Value (2015): 78.96 | Impact Factor (2015): 6.391

\section{References}

[1] Ahmed, Z. (2008); Integrated Perspectives on Ophiolites of Pakistan, IGC, OSLO.

[2] Bailey, E.B. and Mc.Callien. (1953); Serpentine Lavas, Ankara Melange and the Anatolian Thrust, Trans. Roy. Soc. Edinburgh, 62/2, pp. 403-442.

[3] Bandopadhyay, S; Subramanyan, M.R. and Sharma, P.N. (1973); Geology and Mineral Resources of Andaman-Nicobar Islands, Rec. Geol. Surv. India: 105(2), pp. 25-67.

[4] Baranowski, J; Armbruster, J; Seeber, L. and Molnar, P. (1984); Jour. Geophys. Res. 89 (B8), 6918.

[5] Barman, SK, and Tiwari, SK, (2016); Serpentinites: A byproduct of ophiolite quarries for regional development: A case study of South Andaman Island, Bay of Bengal, Online ISSN: 2349-4182, Print ISSN: 2349-5979, Vol. 3; Issue 9; Sept. 2016; Page No. 190196

[6] Bowen, N. L. and Tuttle, O. F. (1949); The system $\mathrm{MgO}-\mathrm{SiO}_{2}-\mathrm{H}_{2} \mathrm{O}$, Bull. Geol. Soc. Am. 60, pp. 439-460.

[7] Bowin, C. J. (1973); Geophys. Res, 78, pp. 6029-6043.

[8] Brogniart, A. (1813); "Essai de classification mineralogique des roches mélanges" Jour. Des Mines, Paris, V. xxxiv, pp.190-199.

[9] Chandra, P. K., Banerjee, A and Chaterjee P. K. (1962); Geology of the Northern part of South Andaman Progress Report of O.N.G.C.

[10] Chaterjee, A. K. (1967); Geology of the main Islands of the Andaman area. Proc. Symp. Upper Mantle Project. Hyderabad, pp. 348-362.

[11] Dilek, Y. and Robinson, P. T. (2004); Eds, Ophiolites in Earth History, Geological Coogan, Geological Magazine, pp. 141-741.

[12] Dilek, Y., Furnes, H., (2011); Ophiolite genesis and global tectonics: geochemical and tectonic fingerprinting of ancient oceanic lithosphere. Geol. Soc. of America Bulletin 123 (3/4), 387411.

[13] Dilek, Y; Flower, M. F. T. (2003); Tethyan Ophiolites in Alpine Himalayan Orogenic System, Arc-Trench roll back and Fore-Arc Accretion. A Model Templet for Ophilites in Albania, Cyprus and Oman in Geol. Soc. London, Sp. Pub. Vol. 218, pp. 43-68.

[14] Dilek, Y; Moores, E., Elthon, D. and Nicolas, A. (2000); Ophiolites and Oceanic Crust: New insights from field Studies and the Ocean Drilling Prog. Eds. GSA Sp. pp. 349, 552 p.

[15] Eldridge,M.Moores; Dilek, Y; Don, E. and Adolf, N. (1998); Ophiolites and Oceanic Crust: New insights from field studies and the ODP, Geol. Soc. Am. (GSA), Sp. Pub.

[16] Eremenco, N. A. and Sastri,V. V. (1978); On the Petroleum Geology of Andaman Islands, Bull. ONGC, Vol. 14, No.1 \& 2, pp. 35-47.

[17] Furnes, H. et al. Geoscience Frontiers 5 (2014); 571603 579: Manipur (India); Andaman; Meratus (SE Borneo); Timor-Tanimbar (Timor); East Sulawesi; Seram-Ambon (Central Indonesia).

[18] Gairola,V.K; Srinivasan,M.S. and Chatterjee, B.K. (1989); Ophiolites of South Andaman and their Tectonic Importance. Current Topics in Geology, Vol. 12, pp. 2711-2718.
[19] Gee, E. R. (1927); Geology of the Andaman and Nicobar Islands with Special reference to Middle Andaman, Rec. Geol. Surv. India, 59, pp. 208-232.

[20] Haldar, D. (1981); Andaman Ophiolites. Three decades of developments in Petrology, mineralogy, petrochemistry in India. Geol. Surv. of India, Jaipur, Proc. Symp, pp. 25-26

[21] Hess, H. H. (1938); A primary Peridotite magma. Am. Jour. Sci. $5^{\text {th }}$ Ser. 35 , pp. 321-344.

[22] Hess, H. H. (1955); Serpentines, Orogeny and Epirogeny, Geol. Sec. Am. Special Paper, 62, pp. 391408.

[23] Karunakaran et. al., (1964); A new probe in to the Tectonic History of the Andaman and Nicobar Islands. Proc. of XXII. Inter. Geol. Cong. Sec. 4, New Delhi.

[24] Kathryn,M.G. and Banerjee, N.R. (1998); Hydrothermal Alteration patterns in Supra-Subduction Zone Ophiolites, Geol. Soc. Am. (GSA), Sp. Pub. pp. 283-300.

[25] Mc. Birney, A. R. (1985); Igneous Petrology, Freeman Cooper and Co.

[26] Mukharjee, K. K. (1976); An Overview of Paleogene Stratigraphy of Andaman Islands with reference to Baratang Island. Rec. Geol. Surv. India 3(2): pp. 65-76.

[27] Oldaham,R.D.(1885); Notes on the Geology of the Andaman Islands, Rec. Geol. Surv. India 18 (Pt.3); pp. 135-145.

[28] Prasad, U. (1985); Ophiolites of India. Rec. Geol. Surv. Ind. 115 (pt.2): pp. 13-24.

[29] Rajendran Kusala, Rajendran C.P. , Earnest Anil , Ravi Prasad G.V., Dutta K. , Ray D.K., Anu R. (2008); Age estimates of coastal terraces in the Andaman and Nicobar Islands and their tectonic implications.

[30] Rassios,A . and Dilek, Y. (2007); Ophiolites as compressive strain-recording media: an example drawn from the Mesohellenic ophiolitic slab, Geophys. Res. Abs, Vol. 9, 01183, European Geosciences Union.

[31] Ratheesh Kumar,R.T., Windley B.F., Rajesh, V.J., Santosh, M. (2013); Elastic thickness structure of the Andaman subduction zone: Implications for convergence of Ninetyeast Ridge.

[32] Ray, J. (2008); Ed. Vol. Ophiolites: Present and Future trends of researches.

[33] Saklani, P.S. (1989); Metamorphic Ophiolites and Orogenic Belts by Today and Tomorrow Printers and Publishers.

[34] Singh, D.D, (1988); Bull. Seismol. Soc. Am., 78, pp. 1510-2115.

[35] Singh, D.D. (1988); Phys. Earth Planet. Inter., 50, pp. 230-239.

[36] Singh, D.D. (1992); Current Science, 62, No 1 and 2, pp. 155-162.

[37] Souriau, A. (1981); Geophys. J. R. Astron. 67, pp. 359374.

[38] Srinivasan, M. S. (1986); Geology of the Andaman and Nicobar Islands with Special Reference to the Nicobars, Mem. Geol. Surv. India. 35, (pt.3), pp. 135-145.

[39] Srinivasan, M. S. (1986); The Geology of the Andaman and Nicobar Islands, J. Andaman Science, Assoc. 2(1), pp. 1-12.

[40] Steinmann, G. (1926); Die ophiolitischen Zonen in den mediterranen Kettengebirgen. Compte-rendu, XIVe 


\section{International Journal of Science and Research (IJSR) \\ ISSN (Online): 2319-7064}

Index Copernicus Value (2015): 78.96 | Impact Factor (2015): 6.391

Congrès Géologique International, 1926, 2, Graficas Reunidas, Madrid, 1927, pp. 637-667.

[41] Tipper, G. H. (1911); Mem. Geol. Surv. India 35, pp. 135-145.

[42] Van Bemmelen, R. W. (1949); The Geology of Indonesia. The Hange, Govt. Printing Office, V.1, pp. 1732.

[43] Wilkinson, J. F.G. (1953); Some Aspects of Alpine Type Serpentinites of Queensland. Geol. Mag., 90, 305321. Amer. Mineralogist. April 2003. V. 88. no. 4. pp. 710.

\section{Author Profile}

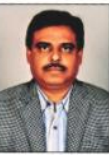

SK Tiwari is Associate Professor and Dy. Director, UGC - ASC (HRDC), Adjunct Faculty, Department of Geology, Centre of Advanced Study, Institute of Pradesh, India

Science, Banaras Hindu University, Varanasi, Uttar

SK Barman is Ph.D Scholar, Department of Geology, Institute of Science, Centre of Advanced Study, Banaras Hindu University, Varanasi, Uttar Pradesh, India. 